\title{
30 YEARS OF THE MINERALOCORTICOID RECEPTOR Short reflections on the discovery of the mineralocorticoid receptor
}

\section{Ronald M Evans}

Howard Hughes Medical Institute, Salk Institute for Biological Studies, La Jolla, California, USA
Correspondence

should be addressed

to R M Evans

Email

evans@salk.edu
Looking back over 30 years, one might assume the fog of time would take its toll, but I still remember the march towards the mineralocorticoid receptor (MR) that began quietly in the summer of 1985 (Fig. 1). We had completed the sequence of the human glucocorticoid receptor (GR), and with the cDNA as probe, found ourselves with a Southern blot which had too many bands for one gene (Fig. 2). I could not get this blot out of my mind, thinking that before my eyes was somehow both a glimpse into our evolutionary past and a possible

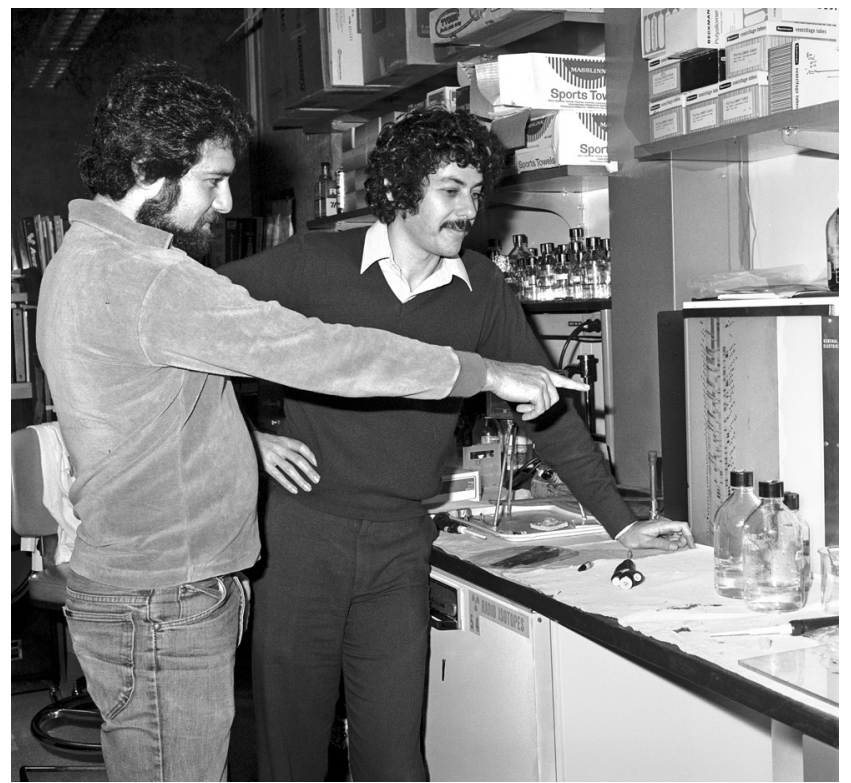

Figure 1

Ron Evans (right) with Neil Birnberg (left) discussing a blot during the GR and MR projects. roadmap for the future: the bands on the gel not only represented new receptor(s) but thus posed a potentially much larger physiological question. Jeff Arriza, a new student in the lab, seized the gauntlet, probably not recognising the challenge it posed. A former submariner, Jeff had to plumb the depths to bring the bands to life (Fig. 3).

After a lot of work, and the usual blind alleys, Jeff had a GR-related receptor: the question was, what was it? Soon he found that it bound and responded to

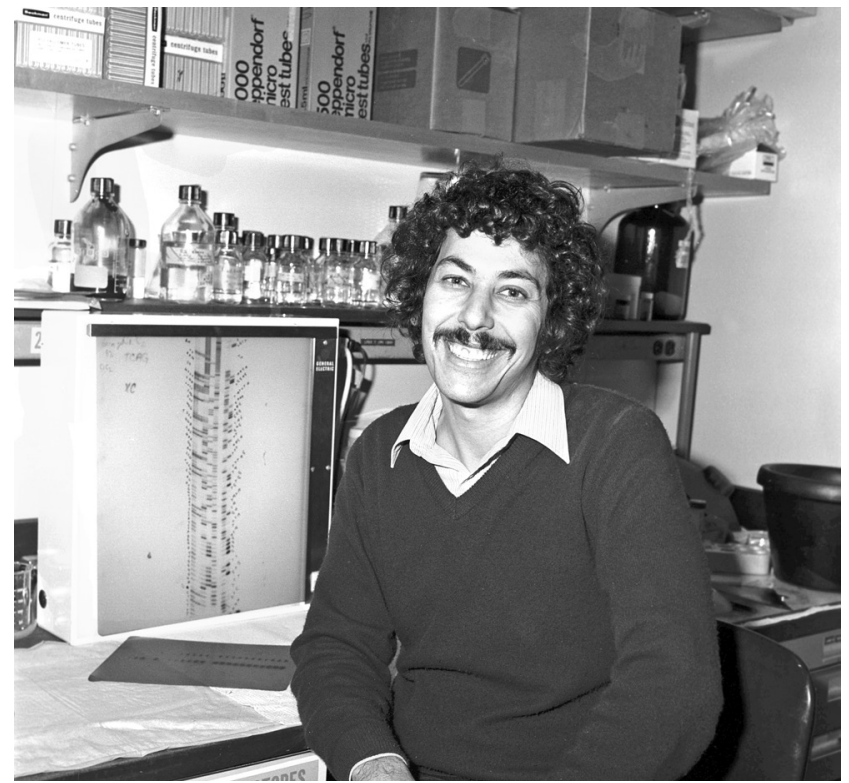

Figure 2

Ron Evans pictured in 1985 with a sequencing gel.

This editorial accompanies a thematic review section on 30 Years of the Mineralocorticoid Receptor. The guest editors for this section were

John Funder and Maria,Christina Zennaroioscientifica.com at 04/26/2023 09:35:02AM 


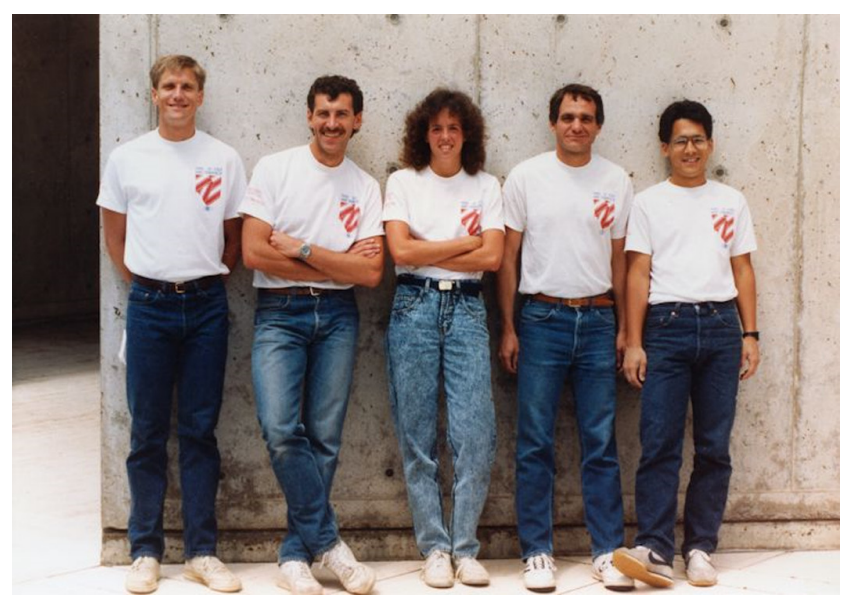

Figure 3

Jeff Arriza (second right) who discovered the MR, pictured with Tony Oro (right) who cloned the first drosophila nuclear receptors, Catherine Thompson (middle) who cloned the neuronal TR, Klaus Damm (second left) who demonstrated that the oncogenic form of the TR was a dominant negative repressor and Stan Hollenberg (left) who was the lead on the hGR paper. aldosterone, leading to Jeff's classic paper in Science describing his discovery and analysis of a full-length and functional human mineralocorticoid receptor (MR), a publication accompanied by John Funder's cheery and informative commentary. I have fond memories of John, sitting in my office at the Salk Institute, and talking to me (at length) about cortisol and aldosterone, and their long history in human health and disease. Izzy Edelman, one of the great physiologists (with whom John trained at UCSF) was then at Columbia; he had speculated in 1962 that aldosterone acted through a transcriptional mechanism, via a nuclear receptor and not a typical binding protein. With Jeff's paper, we finally crossed that threshold and honored Izzy's insight. The rest is history.

Thanks to the Journal of Endocrinology, to all the authors who have contributed and in particular to John Funder for celebrating this auspicious occasion on the 30th anniversary of the birth of the MR.

Received in final form 22 May 2017

Accepted 22 May 2017
Published by Bioscientifica Ltd. 